\title{
Spider Diversity in Different Agricultural Crops in Mangoli, Nainital District, Uttarakhand, India
}

\author{
Jeetikasiddhu $^{1 *} \cdot$ Himanshu Pandey Lohani ${ }^{1}$ • Gunjan Pathak ${ }^{\mathbf{1}}$ - Buddh Raj Kaushal ${ }^{\mathbf{1}}$ \\ ${ }^{1}$ Department of Zoology, D.S.B. Campus, Kumaun University, Nainital-263001, Uttarakhand, India \\ *Corresponding Author Email id: jeetikasiddhu0101@gmail.com
}

Received: 02.04.2021; Revised: 24.05.2021; Accepted: 28.05.2021

(C) Society for Himalayan Action Research and Development

\begin{abstract}
Investigations were carried out on the species composition of spiders in different agricultural crops viz. red lentil, wheat and mixed vegetables (cabbage, carrot, potato, tomato, pea, black eyed beans) at Mangoli in district Nainital of Kumaun region of Uttarakhand, India. The sampling was done using handpicking, ground hand collection, aerial hand collection and sweep netting method. The investigation revealed the presence of 44 spider species belonging to 16 families and 33 genera. The most dominant species was Argiope pulchella comprises highest numbers of individuals (32) and most dominant family was Araneidae (9species). The highest number of individuals was observed from mix vegetable field (296) followed by wheat (209) and red lentil (181). Based on foraging behaviour, the collected spiders were classified into 7 ecological guilds and majority of collected spiders were orb weavers $(37.73 \%)$. Diversity indices: Shannon-Weiner's diversity and species richness of spiders were found to be higher in mixed vegetables crop $(3.57,6.67)$ followed by wheat $(3.47,6.36)$ and red lentil crop $(3.40$, $6.15)$, respectively.
\end{abstract}

Key words: Spider $\bullet$ Agro Ecosystem $\bullet$ Wheat $\bullet$ Mix Vegetables $\bullet$ Orb Weavers

\section{Introduction}

Spiders (Araneae) are generally predators and are very potential biological agent in controlling insect pests in agricultural ecosystems and belong mainly to the families Araneidae, Linyphiidae, Lycosidae, Oxyopidae, Salticidae, Tetragnatidae, and Thomisidae. (Dumas et al., 1964; Luczak, 1979; Edwards, 1990; Souza and Martins, 2005). Biodiversity of spider species in natural ecosystems, including agriculture was high (Riechert and Lockley, 1984; Rypstra et al., 1999; Oberg, 2007). Spider community is closely related to the characteristics of the plant community where they live (Rimbing and Memah, 2008). Spiders (Arachnida:Araneae) are an integral part of biodiversity since they play most important role in ecosystems as predators and sources of food for other creatures. They have clearly established themselves as model organisms in biochemical (silk proteins and venom), behavioural (sexual and web-building behaviours) and ecological (foraging, predator-prey systems and integrated pest management) research (Sebastian et al., 2011). There are currently 48,953 reported spider species placed in 4195 genera and 128 families in the world and, there are many species yet to be identified and described (World Spider Catalogue, 2020). diversity of spider species is also influenced by the structure of landscape, habitat type, and period of plant growth.

Himalayan spider fauna is diverse, but effective conservation is impeded by only few studies (Uniyal and Quasin 2010, 2011) of taxonomic 
knowledge. Abundance of spiders collected varied in three crops. A total of 44 spider species belonging to 33 genera of 16 families were recorded in three different crops (Table 1). Maximum percentage of collected species belonged to the family Araneidae (20.45\%). Maximum numbers of species were recorded in mixed vegetable crop (39 species), followed by wheat (35 species) and red lentils (33 species) (Table1). Clubiona filicata (12), Argiope pulchella (17) and Pardosa pseudoannulata (18) were dominant species in red lentils, wheat and mixed-vegetables, respectively. Maximum number of individuals were recorded in mixed vegetables (296) followed by wheat (209) and minimum in red lentil (181) (Table 2). In terms of individuals, family Araneidae (26.53\%) was dominant followed by Lycosidae (16.47\%), Tetragnathidae (12.97\%), Salticidae (8.45\%), Linyphiidae (7.43\%), Oxyoidae (6.26\%), Therididae (4.08\%), Uloboridae $(2.76 \%)$, Pholcidae, Thomisidae, Philodromidae, Gnaphosidae(2\%), Miturgidae, Clubionidae, Nephillidae and Philodromidae (1\%) (Figure1). In this study, emphasis was focus on specify the diversity of spiders in Kumaun region of Uttarakhand, India. In general, taxonomic studies on spiders and invertebrates of this region are very few. This study focuses on the spiders as a representative invertebrate fauna from this ecosystem. Data thus collected may facilitate future initiatives of biodiversity database of these species in the region.

\section{Materials and Methods}

\section{Study area}

The present study was conducted at Mangoli in district Nainital of Kumaun region (longitude $79.40^{\circ} \mathrm{E}$, latitude $29.35^{\circ} \mathrm{N}$; altitude $540 \mathrm{~m}$ ). Mangoli is a village and a small hill station. It is located $18 \mathrm{~km}$. south west of Nainital. The study sites selected had relatively different vegetation and anthropogenic impacts. Three crops were sampled; from an agricultural land having an area of one hectare near wheat, red lentils and mix vegetables were grown.

\section{Sampling}

The sampling was carried out from November 2018 to April 2019 in agricultural field measuring one hectare with an average sampling interval of 15 days, covering different stages of the crop development. Three crops were sampled: red lentil, wheat and mixed vegetables. Spiders were collected by adopting standard sampling techniques such as sweep netting, hand picking, ground hand collection, and aerial hand collection. Sampling was made between 7:00 A.M. and 11:00 A.M. to minimise spider migration to the lower vegetation stratum due to high temperature at noon (Dumas et at., 1964). Temperature, $\mathrm{pH}$ and moisture of soil were measured and photographs were taken from canon digital camera. The specimens were preserved in $70 \%$ alcohol and adult specimens were identified up to species level, sub adults and juveniles were identified up to genus level by using Leica S9 stereo zoom Diaplan fluorescent microscope with the help of various keys Tikader and Biswas (1981), a hand book of "Spiders of India" (Sebestian and Peters, 2009), Platnick (2010) and the world spider catalogue (2020). 

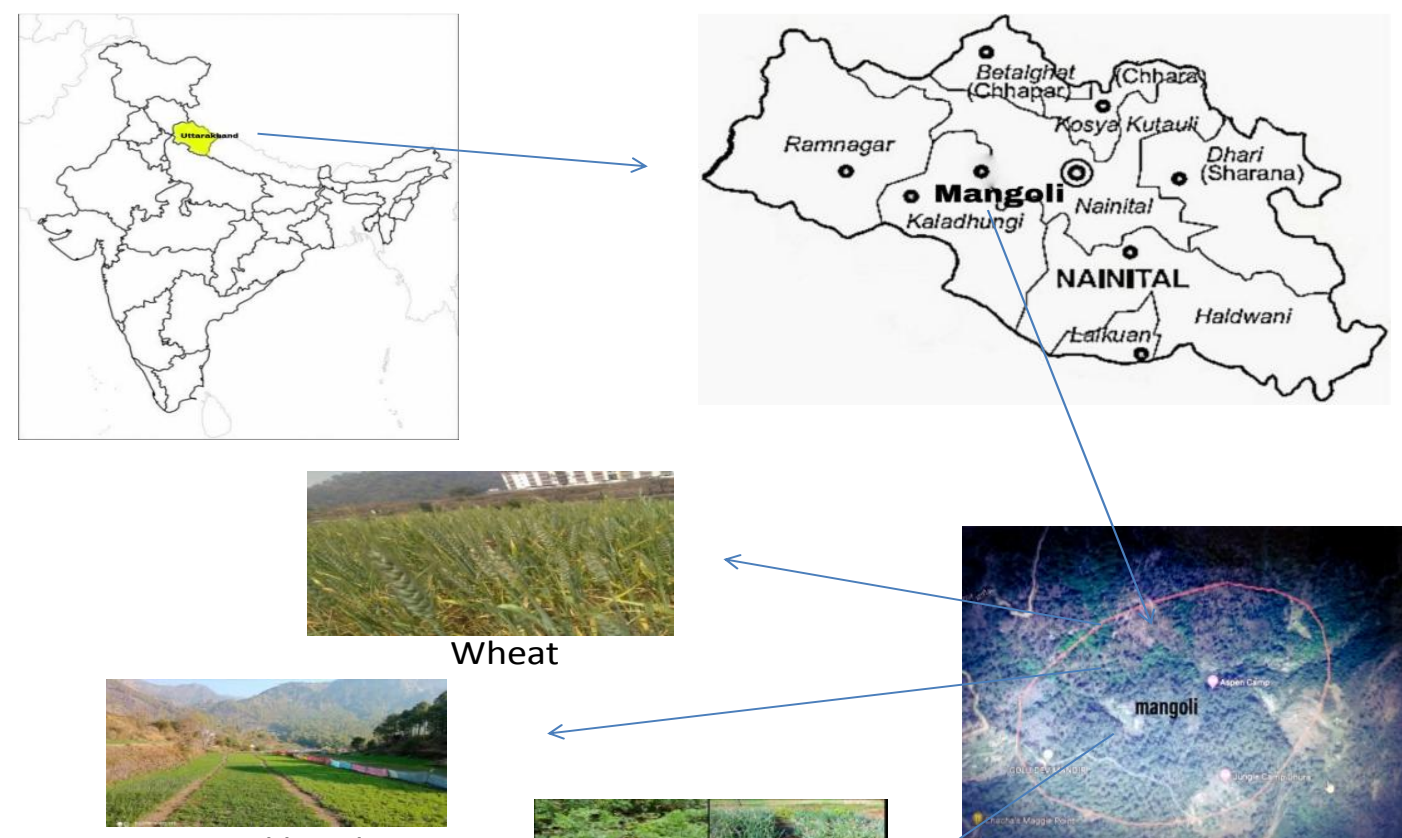

Red lentils
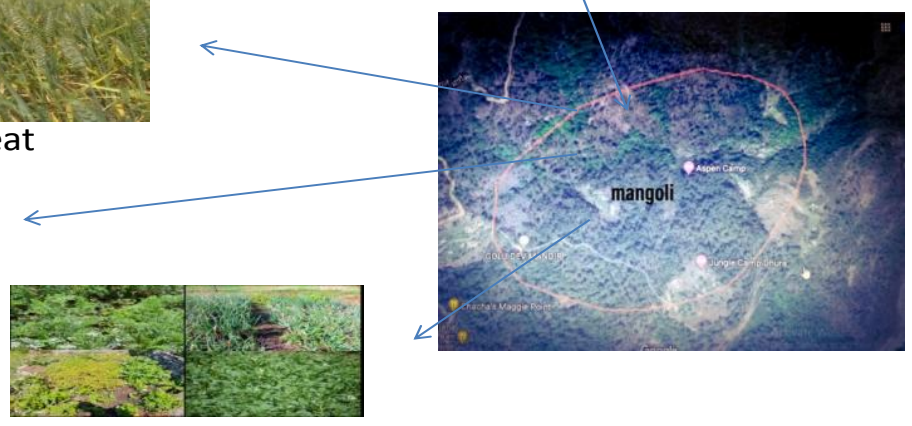

Mix vegetables

Fig 1. Study site of Mangoli district Nanital

\section{Data analysis}

The Shannon-Wiener, Species Richness (SR) and Equitability (J) were used to calculate the spider's diversity.

Shannon-Wiener (1949) diversity index was calculated by using equation $\mathrm{H}^{\prime}=\Sigma \mathrm{Pi}(\operatorname{lnPi})$ where, $\mathrm{Pi}$ is the proportion of each species in the sample.

Species Richness (SR) was calculated by Margalef (1958) formula: (S-1)/ $\log N$, where $S=$ total number of species and $\mathrm{N}=$ total number of individuals present in the sample.

Equitability ( $\mathrm{J}$ ) was calculated by using M Lloyd (1964) formula: $=\mathrm{H} / \mathrm{Hmax}$, where $\mathrm{H}=$ sum of $\mathrm{Pi}$ $(\operatorname{lnPi}), \mathrm{Hmax}=\ln$ total number of species.

\section{Result and Discussion}

Spiders collected in the study site were grouped into 8 classification systems of spider guild proposed by Utez et al., (1999). Spider guild composition of the three crops is shown in (Figure2). Seven guilds of spiders were: orbweavers, ground runners, branch dweller, wandering sheet weavers, space web builders, funnel weavers small except foliage runners that were absent in wheat crop.All crops were dominated by the orb-weavers $(37.73 \%)$ followed by branch dweller (20.75\%), ground runners (17.92\%), wandering sheet weavers $(8.49 \%)$, space web builders $(7.54 \%)$, foliage runners $(4.71 \%)$ and funnel weavers (2.81\%)(Figure 2).

Species richness and diversity of spiders are given in (Table3) diversity indices recorded in maximum in mixed vegetables (3.57), followed by wheat (3.47), and red lentil crop (3.40). species richness also was higher in mixed vegetables 
(6.67), followed by wheat (6.36), and red lentil (6.15). similarly maximum number of individuals(296), and number of species (39) were recorded in mixed vegetables, in wheat field number of individuals (209), and number of species (35), and number of individuals (181), number of species (33) in red lentil. results of the study indicate that a good diversity was observed in all crops.

Table 1: Checklist of Spiders and their abundance in red lentil, wheat and mix vegetables field crop field (November 2018 to April 2019) (+present;-absent).

\begin{tabular}{|c|c|c|c|c|}
\hline Family & Species & Red Lentil & Wheat & $\begin{array}{l}\text { Mix } \\
\text { vegetables }\end{array}$ \\
\hline \multirow[t]{9}{*}{ Araneidae } & Araneus mitificus(Simon,1886) & - & + & + \\
\hline & Argiope catenulate (Doleschall, 1859) & + & + & + \\
\hline & Argiope pulchella (Thorell,1881) & + & + & + \\
\hline & Cyclosa bifida (Doleschall, 1859) & + & + & + \\
\hline & Cyclosagossypiata (Keshwani, 2013) & - & + & + \\
\hline & Cyrtophoracitricola (Forsskal, 1775) & + & + & + \\
\hline & Neoscona nautical (L Koch, 1875) & + & + & + \\
\hline & Neoscona theisi(Walckenaer, 1841) & + & + & + \\
\hline & Neoscona mukerjei (Tikader, 1980) & - & + & + \\
\hline Clubionidae & Clubionafilicata (O.P.Cambridge) & + & - & - \\
\hline Gnaphosidae & $\begin{array}{l}\text { Gnaphosadege (Ovtsharenko, Platnick\& } \\
\text { Song, 1992) }\end{array}$ & + & + & + \\
\hline \multirow[t]{3}{*}{ Linyphiidae } & Nerienebirminica (Thorell, 1887) & + & + & + \\
\hline & Linyphia spl & + & + & + \\
\hline & Linyphia sp2 & + & + & + \\
\hline \multirow[t]{6}{*}{ Lycosidae } & Hippasaagelenoides (Simon, 1884) & + & + & + \\
\hline & Hogna sp.(Genus:Honga Simon, 1885) & + & - & - \\
\hline & Lycosa tista (Tikader, 1970) & + & - & + \\
\hline & $\begin{array}{l}\text { Pardosapseudoannulata (Bosenberg and } \\
\text { Strand, 1906) }\end{array}$ & + & + & + \\
\hline & Pardosasumatrana (Thorell, 1890) & + & + & + \\
\hline & Paradosa sp.1 & + & + & + \\
\hline Miturgidae & Churacanthiuminclusum (Hentz, 1847) & + & - & + \\
\hline Nephillidae & Nephila pilipes (Fabricius, 1793) & - & + & + \\
\hline \multirow[t]{3}{*}{ Oxyopidae } & Oxyopesjavanus (Latreille, 1804) & + & + & + \\
\hline & Oxyopes spl & + & + & + \\
\hline & Oxyopes sp2 & + & + & + \\
\hline Pholcidae & Pholcusphatangoides (Fuesslin, 1775) & - & + & + \\
\hline \multirow[t]{2}{*}{ Philodromidae } & $\begin{array}{l}\text { Philodromuschambaensis (Tikader, } \\
\text { 1980) }\end{array}$ & + & - & - \\
\hline & Philodromus sp.1 & + & - & - \\
\hline Psechridae & Psechrushimalayanus(Simon, 1906) & + & + & + \\
\hline
\end{tabular}




\begin{tabular}{|c|c|c|c|c|}
\hline \multirow[t]{7}{*}{ Salticidae } & Carrhotus spl & + & - & - \\
\hline & Carrhotus sp2 & + & + & + \\
\hline & Hyllus semicupreus (Simon, 1885) & - & - & + \\
\hline & Plexippuspaykulli (Audouin, 1826) & - & - & + \\
\hline & Rhenedanieli (Tikader, 1973) & - & + & + \\
\hline & Rheneflavigera (Cl. Koch, 1846) & - & + & + \\
\hline & $\begin{array}{l}\text { Stenaelurillus } s p .(\text { Genus Stenaelurillus } \\
\text { Simon, 1839) }\end{array}$ & - & + & + \\
\hline \multirow[t]{4}{*}{ Tetragnathidae } & $\begin{array}{l}\text { Tetragnathamandibulata (Walckenaer, } \\
\text { 1842) }\end{array}$ & + & + & + \\
\hline & Tetragnathajavana (Thorell, 1890) & + & - & + \\
\hline & Tyloridastriata (Thorell, 1877) & + & + & + \\
\hline & Tyloridaventralis (Thorell, 1877) & + & + & + \\
\hline Theridiidae & $\begin{array}{l}\text { Argyrodesargentatus(O.P. Cambridge, } \\
\text { 1880) }\end{array}$ & + & + & + \\
\hline Thomisidae & $\begin{array}{l}\text { Achaearaneamundula } \\
\text { 1963) }\end{array}$ & + & + & + \\
\hline \multirow[t]{2}{*}{ Uloboridae } & Zosisgeniculata (Olivier, 1789) & - & + & + \\
\hline & Ulobous sp.1 & + & + & + \\
\hline
\end{tabular}

Table 2: List of the spiders collected from three habitat type of field crops; red lentil wheat and mixvegetables (November 2018 to April 2019)

\begin{tabular}{lllllll}
\hline Family & Red lentil & & Wheat & \multicolumn{2}{c}{ Mix vegetables } \\
\cline { 2 - 7 } & Genera & Species & Genera & Species & Genera & Species \\
\hline Araneidae & 4 & $6(42)$ & 5 & $9(67)$ & 5 & $9(73)$ \\
Clubionidae & 1 & $1(12)$ & 0 & 0 & 0 & 0 \\
Gnaphosidae & 1 & $1(4)$ & 1 & $1(5)$ & 1 & $1(8)$ \\
Linyphiidae & 2 & $3(12)$ & 2 & $3(15)$ & 2 & $3(24)$ \\
Lycosidae & 4 & $6(33)$ & 3 & $5(31)$ & 3 & $5(49)$ \\
Miturgidae & 1 & $1(6)$ & 0 & 0 & 1 & $1(6)$ \\
Nephillidae & 0 & 0 & 1 & $1(4)$ & 1 & $1(5)$ \\
Oxyopidae & 1 & $3(13)$ & 1 & $3(11)$ & 1 & $3(19)$ \\
Pholcidae & 0 & 0 & 1 & $1(6)$ & 1 & $1(9)$ \\
Philodromidae & 1 & $2(7)$ & 0 & 0 & 0 & 0 \\
Psechridae & 1 & $1(4)$ & 1 & $1(5)$ & 1 & $1(8)$ \\
Salticidae & 1 & $2(6)$ & 3 & $4(22)$ & 5 & $6(30)$ \\
Tetragnathidae & 2 & $4(28)$ & 2 & $3(22)$ & 2 & $4(39)$ \\
Therididae & 1 & $1(5)$ & 1 & $1(9)$ & 1 & $1(14)$ \\
Thomisidae & 1 & $1(6)$ & 1 & $1(3)$ & 1 & $1(5)$ \\
Uloboridae & 1 & $1(3)$ & 2 & $2(9)$ & 2 & $2(7)$ \\
TOTAL & 22 & $33(181)$ & 24 & $35(209)$ & 27 & $39(296)$ \\
\hline
\end{tabular}


Table 3: Diversity Indices of Spider species in red lentil, wheat and mix vegetables crop field (November 2018 to April 2019)

\begin{tabular}{|c|c|c|c|c|}
\hline Diversity Index & & Red Lentil Field & Wheat Field & Mix Vegetables Field \\
\hline $\begin{array}{l}\text { Shannon-Weiner's } \\
\text { (H') }\end{array}$ & Diversity & 3.40 & 3.47 & 3.57 \\
\hline Margalef (SR) & & 6.15 & 6.36 & 6.67 \\
\hline Species numbers & & 33 & 35 & 39 \\
\hline Total Individuals & & 181 & 209 & 296 \\
\hline
\end{tabular}

The Mangoli village of Kumaun region of Uttarakhand is enriched with different agricultural and horticultural crops. The major crops in Mangoli are red lentil, wheat, rice, ragi, black eyed bean, tomato, potato, pea, carrot and cabbage etc. Research on spider diversity in agro ecosystems is highly valuable; both to observe the effect of such predators have on herbivorous pest (Maloney et al., 2003) and to understand how profound changes on the environment affect spider colonisation (Oberg 2007). Araneidae, an orb-weaver spider family was the most dominant on all crops. The complex plants with relatively open branches or twigs are considered as a suitable habitat by the Araneidae for constructing their web.generally they construct their webs on vertically. Lycosidae was the second most abundance in mixed- vegetables crop than other crops in the present study. Lycosidae inhabits and hunts their prey on open ground; they also were found climbing on leaves, especially on low vegetation such as on the mixed-vegetables. Tetragnathidae was the third most dominant in each habitat type, the angle of the web is typically somewhere between vertical and horizontal and also uses webs to capture prays.

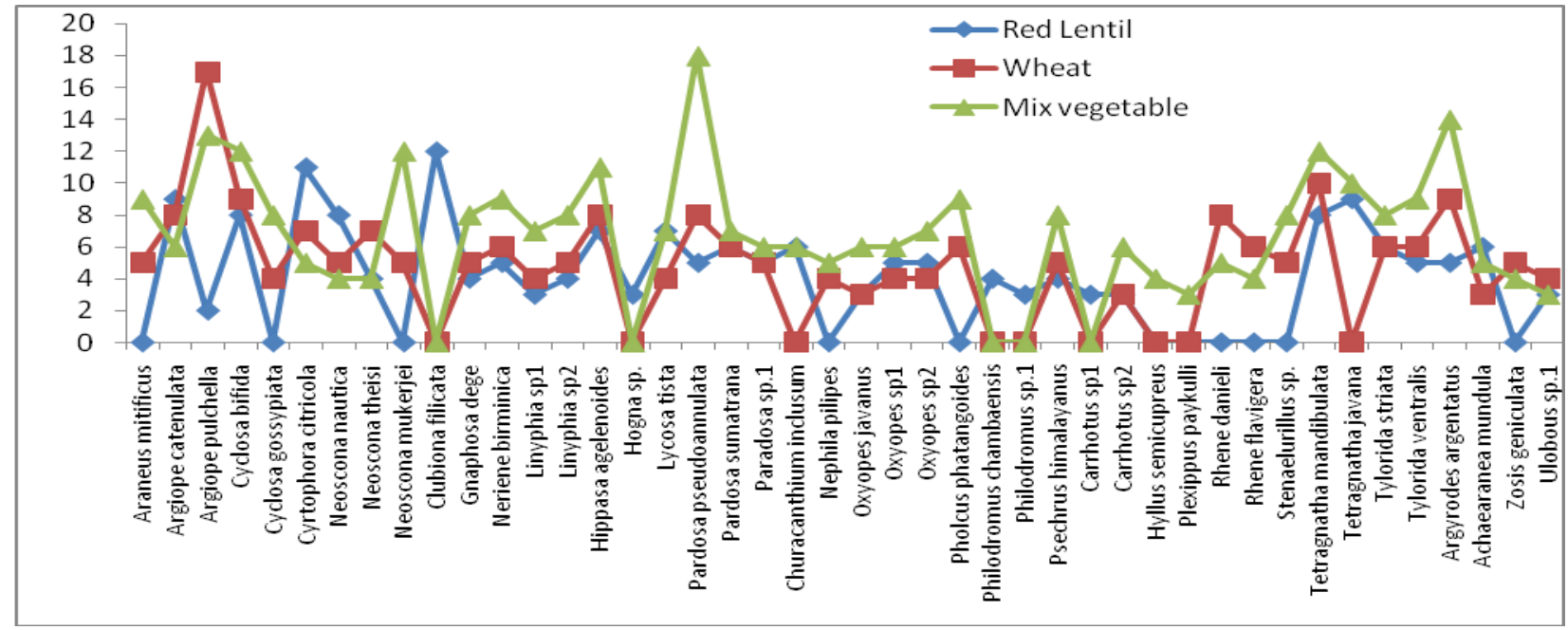

Figure 1: Species diversity of spiders in red lentil, wheat and mix vegetables crop field (Nov 2018 to April 2019) 


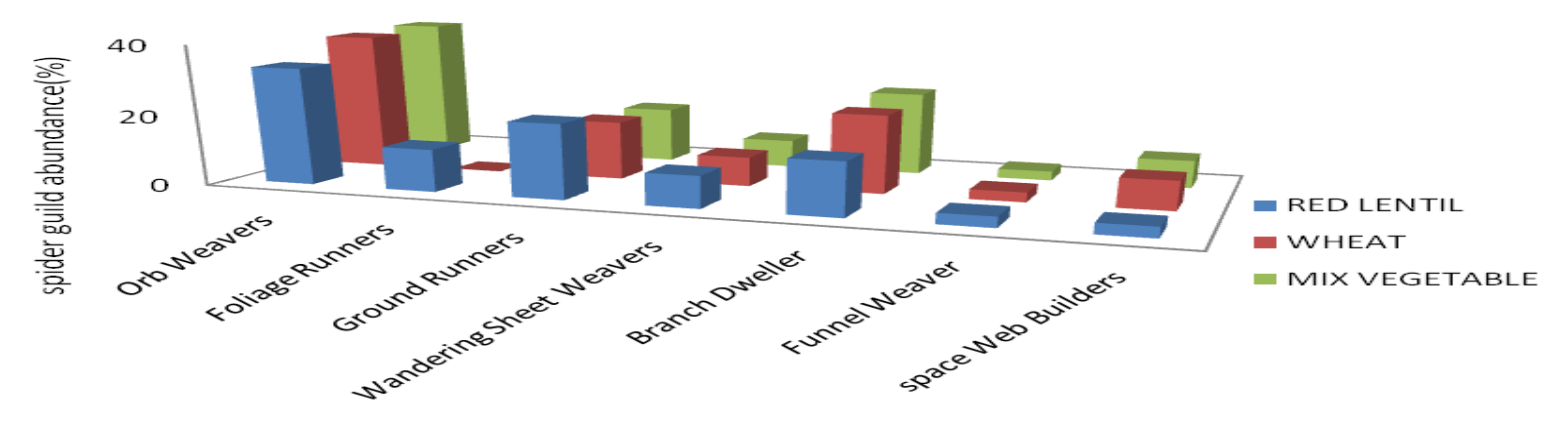

Figure 2: Guild structure of spiders in red lentil, wheat and mix vegetables crops

Differences in crop structure, size, number of leaves, twigs, branches, spaces in between branches, twigs, and leaves, and leaf and canopy shape affect the availability of species of the families of Araneidae, and Lycosidae (Souza and Martins, 2005). Species composition and their richness recorded in the present study indicate that the habitat structure and vegetation complexity influenced the presence of spider species as has also been reported by Valcerde and Lobo (2007). Mixed-vegetables crop was thus more populated than wheat and red lentil crops in the present study also (Figure 1). Differences in abundance, diversity and richness of spider species in any habitat types are affected by various factors, such as habitat complexity. The three habitat crops in the observation can be classified into two habitat groups: (1) plant with many (complex) branches is mix vegetables and less (complex) branches in wheat, and (2) plant with simple branches is red lentils. diversity of spider species was probably significantly different between mixed-vegetables, wheat and red lentil due to habitat complexity in the present study also. The results in the present study show an association between the structural complexity of the plant to the species abundance, diversity and richness. high density of leaves and branches, and more complex twigs in mix vegetables make them good habitats for the canopy dweller spiders. The physical structure and the density of the plants provide good living conditions for the spiders to construct webs, hiding place or shelter, prey availability, microclimatic conditions such as temperature and humidity, mating activity, and competition (Dumas et al., 1964; Luczak, 1979; Oberg, 2007; Warghat et al., 2010).

According to Root (1967), guilds are groups of ecological organisms which utilized similar or a single resource in a similar style, Orb-weavers (37\%) were dominant in mixed-vegetables crop in the present study also, then by the branch dwellers, (20\%) and ground runners (17\%) (Fig.2). In general, the structure of spider guild is influenced by the host plant, the diversity, the microenvironment, and the level of disturbance (Luczak, 1979; Edwards, 1990; Hurd and Fagan, 1992). Complexities of the crop structure determine the composition of spider guild, and indirectly affect the level of herbivore damage (Edwards, 1990).All habitat crops are usually dominated by the orb-weavers followed by the ground runners and space web builders (Sebestian and Peters, 2009). The present study also showed significant variations in the population density, species richness and diversity among the different habitats and crops. Recent experimental with the studies suggest that habitat structure manages diverse assemblages of spiders and are in conformation with the studies of Uetz(1999).

\section{Conclusion}


The total of spider 686 individuals of spiders belonging to 44 species, 33 genera, and 16 families were collected. Of these, a total of 296 individuals belonging to 39 species from mixedvegetables crops; 209 individuals, belonging to 35 species from red lentil crop; and 181 individuals belonging to 33 species from wheat crop were collected. Species diversity similarly, species richness was 6.67 in mixed vegetables crop, 6.36 in wheat crop and 6.15 in red lentil crop.The results of the presents study indicate that mixed vegetables crop was the most favourablefor spiders in terms of number of individuals, and species collected and diversity.

\section{Acknowledgements}

Authors wish to acknowledge Head of the Department of Zoology, D.S.B. Campus, Kumaun University, Nainital for providing the basic facilities and infrastructure during the present study.

\section{References}

Chen B and Wise DH, (1999) "Bottom-Up Limitation of Predaceous Arthropods in a Detritus-Based Terrestrial Food Web," Ecology, 80: 761-772.

De Souza ALT and Martins RP, (2005)"Foliage Density of Branches and Distribution of Plant-Dwelling Spiders1,"Biotropica, 37: 416-420.

Dumas BA and Boyer WP, Whitcomb W, (1964) Effect of various factors on surveys of predaceous insects in soybeans. J. Kans. Entomol. Soc. 37: 192-201.

Edwards GB, (1990) "Spiders in United States field crops and their potential effect on crop pests," J Arachnol, 18: 1-27.

Halarnkar MM, Pai IK, (2018) "Distribution, Diversity and Ecology of Spider Species At
Two Different Habitats" Int. J Env. Sci Nat Resu., 8: 2572-1119.

Hurd LE and Fagan WF (1992) "Cursorial spiders and succession: age or habitat structure?," Oecologia, 92: 215-221.

Hurd LE, RP, WF and Fagan RP, (1992) "Cursorial spiders and suc succession: age or habitat structure?" Oecologia, 92: 215221.

Luczak J, (1979) "Spiders in agrocoenoses," Polish Ecological Studies, 5: 151-200.

Lubin YD, (1978) "Seasonal abundance and diversity of web building spiders in relation to habitat structure on Barro Colorado I Panama" J. Arach., 6(1): 31-51.

Memah VV, Tulung M, Waroun $\mathrm{J}$ and Redsway R.T.D. Maramis, (2014) "Diversity of spider sp. In some agricultural crops in North Suluwesi, Indonesia" Int. J. SCi Eng Res., 5: 2229-5518.

Maloney D, Drummond FA and Alford R, (2003) "Spider predation in agroecosystems: Can spiders effectively control pest populations?" Tech. Bull. Maine Agri Forest Exp. Stat., 190 (4): 28.

Oberg S, (2007) "Diversity of spiders after spring is sowing - influence of farming system and habitat type" Journal of Applied Entomology 131 (8): 524-531

Platnick, NL (2010) The world spider catalog, version 10.5, American Museum of Natural History.

http;//research.amnh.org/iz/spider/catalog/I ntro3.html.

Quasin S and Uniyal VP (2010) "Preliminary investigation of spider diversity in Kedarnath Wildlife Sanctuary, Uttarakhand, India" Indian Forester, 136(10): 1340-1345

Quasin S and Uniyal VP (2011) "Spider diversity along altitudinal gradient in milam valley Nandadevi biosphere reserve, Western Himalaya" ENVIS Bulletin: 
Arthropods and their Conservation in India (Insects \& Spiders) 14: 219-232.

Riechert SE and Lockley T (1984) "Spiders as Biological Control Agents," Annual Review of Entomology, 29: 299-320.

Rypstra AL, Carter PE, Balfourd RA and Marshall SD (1999) "Architectural features of agricultural habitatsand their impact on the spiders inhabitants" The J Arach., 27: 371-377.

Root RB (1967) "The niche exploitation pattern of the blue-gray gnatcatcher" Eco. Monogr., 37: 317-350.

Rimbing S and Memah V (2008) "Jenis dan kelimpahan arthropoda predator pada beberapa habitat tanaman kedelai di Minahasa Utara," Jurnal Eugenia, 14: 436444.

Sebestian PA and Peters KV (2009) Spiders of India. University Press Publication, India.

Sebastian PA, Mathew MJ and Murugesan S (2011) "Spider fauna in the forest and agricultural ecosystems of central Kerala, India" Arthropods and their Conservation in India (Insects \& Spiders), ENVIS Bulletin : Wildlife \& Protected Areas, 14: 159-174.

Souza De ALT and Martins RP (2005) "Foliage Density of Branches and Distribution of Plant-Dwelling Spiders1," Biotropica, 37: 416-420.

Tikader BK and Biswas B (1981). Spider fauna of Calcutta and vicinity: Part 1. Rec. Zoo. Surv. India, Occasional Paper 30: 1-49.

Uetz GW (1991) "Habitat structure and spider foraging," in Habitat structure: the physical arrangement of objects in space, S. S. Bell, E. D. McCoy, and H. R. Mushinsky, Eds. London: Chapman and Hall.

Uetz, G.W., Halaj, H. and Cady, A.B. (1999). Guild structure of spiders in major crops. The J Arach., 27:270-280.
URL:https://link.springer.com/article/10.1007/s1 1252-006-0002-7 Fetched: 2/16/2021 9:46:00 AM

URL:https://www.redalyc.org/pdf/425/4252088 5012.pdf Fetched: 2/16/2021 9:46:00 AM

URL:175eccf2-f970-4251-9d0a-bc28ddc7ea71 Fetched: 3/7/2019 3:10:29 PM

URL:http://14.139.121.106:8080/xmlui/bitstrea $\mathrm{m} / \mathrm{handle} / 123456789 / 1431 / 18 . \% 20$ Summar y.pdf Fetched: 2/16/2021 9:46:00 AM.

URL:https://www.researchgate.net/publication/2 29938519_Determinants_of_local_spider_ Ar ... Fetched: 2/16/2021 9:46:00 AM

URL:5293eb53-69bc-4ae9-8922-a94f0fd4caa8 Fetched: 4/4/2019 5:05:18 AM

Valverde AJ and Lobo JM, (2007) "Determinants of local spider (Araneidae and Thomisidae) species richness on a regional scale: climate and altitude vs. habitat structure" Eco. entomo., 32(1): 113122.

Wissinger SA, "Cyclic Colonization in Predictably Ephemeral Habitats: A Template for Biological Control in Annual Crop Systems," Biological Control, 10: 1997.

Warghat NE, Sarma NR, Chirde SG and Chandrasekar MR, (2010) "Distribution of spiders from foot hill agricultural fields of Satpura mountain range of Amravati district, Maharashtra, Indi”. Bio Sci Biotech Res Comm 3(2): 150-153.

Wise, D.H.(1993) "Spiders in Ecological Webs. "Cambridge University Press, London.

World Spider Catalogue (2020) Natural History Museum Bern, online at htt://wsc.nmbe.ch, Version 21.5 (accessed 12. VIII).

$$
* * * * * * *
$$

